Roberts's paper the gaseous explosions committee of the British Association. The alloys research committee of the Institute of Mechanical Engineers; the newly established research committee of the electrical engineers; the reinforced concrete committee of the civil engineers; or the Government Advisory Committee for Aëronautics, are all instances. For the success of such committees three things are needed-a man or men to carry out the research, a laboratory or works with proper equipment for the experiments, and funds to defray the expenses.

Prof. Hopkinson did well in the discussion at Cambridge to direct attention to the individuality of research. Much-everything--depends on the man, and he must have freedom. The committee may specify the objects of the inquiry, and indicate in general terms the methods to be followed, but no real result will ensue unless the investigator has ideas of his own, and, after the suggestions laid before the committee are approved, is free to carry them out.

The gaseous explosions committee owes its success to Dugald Clerk and Hopkinson; the alloys research committee to Roberts-Austin, Carpenter, and Rosenhain; while the work of the Advisory Committee for Aëronautics would lose nearly all its value were it not for the energy and devotion of the staff of the National Physical Laboratory.

Engineering research-technical research, indeed, of all kinds-differs, however, from much scientific research in that it can be organised. The problems proposed are usually fairly definite. What are the properties of a certain series of alloys? How are they modified by temperature, forging, annealing, and the like? Do the results of impact tests depend on the form and dimension of the specimen? What is the exact series of changes of temperature and pressure in the cylinder of a gas-engine? How are the forces and couples on an aerroplane related to its aspect to the wind? The problems may be difficult, the answers may elude inquiry; but, given the man, the laboratory, and the funds, a committee meeting at intervals to discuss the results of the experiments may reasonably hope in time to meet with success.

Sir Frederick Donaldson and his colleagues have raised questions of great interest and importance, well worth the careful consideration of those engaged in bringing the results of scientific inquiry to bear on the problems of manufacture and construction.

\section{HIGHER EDUCATION AND THE STATE.}

I ORD HALDANE had something important to say upon the subject of provision for higher education in the course of his speech at the opening of the new buildings of the department of applied science of the University of Sheffield on Saturday last. An account of his address will be found elsewhere in this issue, but we are more particularly interested in a summary of the main points, communicated by him to representatives of the Press. Lord Haldane explained that he desired it to be realised fully that he was announcing the considered decisions of the Cabinet upon the subject of university education, and was indicating the policy to be followed. The substance of his remarks was expressed as follows :-

The main features of the Board of Education's scheme are a recognition of the great strides being made in university education by the United States and Germany, and an intention to maintain closely the connection between pure science and applied science and to check any tendency on the part of any of the younger universities to cultivate the latter at the expense of the former. Theory and practice must keep together. Men of business must remember that much of what is distinctive in the inventive and industrial genius of this country comes from theoretical sources.

Unless we wake up fully about this matter of education, and particularly higher education, I am a little nervous as to what the state of things with regard to our industrial supremacy will be fifteen or twenty years hence.

The nation will have to make up its mind to give considerably more out of central funds. The plans for these advances are now fashioned. I hate any idea of increasing expenditure, whether out of local or national sources, if it can be avoided. But this cannot be avoided. It is salvage money, and unless you spend it you will go back as a nation, and your revenues by which you keep up your fleets and your armies will begin to shrink, because you will not be holding your own in that great industrial position from which your power and your wealth have come.

We have now, therefore, a definite statement of the position which university work is to take in the national scheme of education adumbrated by various Ministers since the beginning of this year. There is a clear acknowledgment of the fact that in the matter of State provision for higher education we have not kept pace with other progressive nations; that scientific work which has no industrial interest is as important as that of which the direct application can be seen; that national advancement can be secured best by increase of scientific knowledge; and that all these things involve contributions from the national exchequer greatly in excess of those hitherto given.

Readers of NATURE scarcely need reminding that the policy thus broadly outlined has been urged consistently and persistently in these columns. Ten years ago, Sir Norman Lockyer, in his presidential address to the British Association at Southport, gave the evidence from which each one of the points mentioned by Lord Haldane could be justified; and since then, year by year, particulars have been given in the reports of the British Science Guild of the progress being made in the endowment of higher education and research abroad, in comparison with the position in this country. It was shown, for instance, in the last report of the Guild, that the total receipts of universities in the United States in the year I9IoI9I I amounted to nearly nineteen million pounds, and the benefactions to four and a half millions. In the same year, the total receipts of those universities and university colleges in Great Britain 
in receipt of grants from the Board of Education was little more than $600,000 l$., of which amount the total State grant was roughly one half. The State grants to universities in Prussia alone are more than twice as much as are contributed to our universities from the national exchequer.

Lord Haldane may therefore safely say that the United States and Germany have made far greater strides in university education than have been undertaken in this country. When he wrote the introduction to Sir Norman Lockyer's collection of addresses on education and national progress (rgo6), he suggested that the private donor should be encouraged, but that the motto of the Chancellor of the Exchequer as regards expenditure upon matters connected with higher education and research should be Festina lente. "I do not mean," he wrote, "that the Government ought not to spend public money generously upon the universities. I mean that it should not be spent unless and until a case for the necessity of such expenditure has been clearly made out."

We may be permitted to conclude from the address at Sheffield that Lord Haldane is now of the opinion that a case has been made out for increased national provision for our educational forces. He knows as well as anyone that the great advances being made in education in other countries constitute a formidable menace to ourselves, and that the State can wait no longer for like developments if it desires to maintain a leading position among progressive peoples. $\mathrm{He}$ has now stated authoritatively that the Cabinet realises our weakness, and accepts the only policy which will remedy it. We have read this pronouncement with lively satisfaction, and shall welcome any measure which will put the policy into effect.

\section{DR. LUCAS-CHAMPIONNIERE.}

THE sudden death of Dr. Just Lucas-Championnière has brought regret to many surgeons in this country, who knew the excellence of his character and of his work. He was seventy years old, surgeon to the Hôtel Dieu (the great hospital in Paris, founded by Saint Louis)-Commander of the Legion of Honour, and member of the French Academy. His father was the first editor of one of the chief medical journals of France; his grandfather had been a leader in the heroic war of $\mathrm{La}$ Vendée. From the Collége Rollin, Lucas-Championnière went to the Hôtel Dieu as a student, and was interne there in 1865 . He became one of the most eminent of all French surgeons of his time, and received honours from many countries, including the Fellowship of the Royal Colleges of Surgeons of London and of Edinburgh. He was a great "all-round" surgeon; but he gave especial study to the operative treatment of hernia, and to the management of fractures. His best recreation-so far as he had time for it-he found in music.

To us over here-some of us may remember his genial presence in London during the $188 \mathrm{I}$ International Medical Congress-he stands for the introduction into France of Lister's antiseptic method. He in France, and Saxtorph in Denmark, were the teachers of the new learning. He came to Glasgow in 1868, and Edinburgh in 1875 , that he might learn for himself, watching Lister himself, every detail of the method. $\mathrm{He}$ so worshipped the work of Lister that, in the later years of his life, he resented the changes of method, the preference for things "aseptic" over things "antiseptic"; he hoped that surgery would return to "Lister's own method." There are few surgical books more pleasant to handle than his "Pratique de la Chirurgie Antiseptique"-with its portrait of Lister for a frontispiece, and the loyalty and devotion of the writing. It is pitiful to think how slow was the spread of the new learning ; what misery was added, for want of the antiseptic method, to the misery of the Franco-German War; what unbelief, and worse than unbelief, delayed the universal recognition of Lister even in our own country.

\section{NOTES.}

A Royal Commission has been appointed to inquire into the subject of venereal diseases in the United Kingdom. The terms of reference are:-To inquire into the prevalence of venereal diseases in the United Kingdom, their effects upon the health of the community, and the means by which those effects can be alleviated or prevented, it being understood that no return to the policy or provisions of the Contagious Diseases Acts of $1864,1866,1869$ is to be regarded as falling within the scope of the inquiry. The members of the Commission are:-Lord Sydenham of Combe, G.C.S.I., F.R.S. (chairman), the Right Hon. Sir David Brynmor Jones, K.C., M.P., Mr. Philip Snowden, Sir Kenelm E. Digby, G.C.B., K.C., Sir Almeric FitzRoy, K.C.B., Sir Malcolm Morris, K.C.V.O., Sir John Collie, Dr. A. Newsholme, Canon J. W. Horsley, the Rev. J. Scott Lidgett, Dr. F. W. Mott, Mr. J. E. Lane, Mrs. Scharlieb, Mrs. Creighton, and Mrs. Burgwin. The secretary to the Commission is Mr. E. R. Forber, of the Local Government Board, to whom any communications on the subject may be addressed.

By Order in Council dated October 14 new denominations of standards of the metric carat of 200 milligrams and its multiples and submultiples have been legalised for use in trade in the United Kingdom on and after April I, I9I4. The permissible abbreviation of the denomination "metric carat" is "C.M." The weights legalised range from 500 C.M. to 0.005 C.M., the series being 5,2 , I throughout. The legalisation of the metric carat has been undertaken by the Board of Trade after consulting representatives of the trade in diamonds and precious stones, and is the outcome of a resolution passed at the General Conference on Weights and Measures, held in Paris in 1907, advocating the adoption of an international standard carat. Diamond dealers in this country were at first opposed to any change, and it is only quite recently that they have found it necessary to reconsider their views on NO. 2296, VOL. 92] 